\title{
De la tradiție la inovație în filosofia și metodologia științei contemporane: „Trietica contradictoriului”, Ștefan Lupașcu ${ }^{1}$
}

Iulia INGLIS ${ }^{*}$

1 Universitatea de Stat din Moldova; iuliainglis@gmail.com

* Correspondence: iuliainglis@gmail.com

\begin{abstract}
Lupașcu, ca un epistemolog, pledează pentru un dialog deschis cu noile descoperiri stiintifice. El propune o teorie a cunoașterii bazată pe dualitate antagonistă în care fenomenele nu sunt liniare și statice, dar dinamice și ritmice. Cunoașterea este privită ca dualitate în care fenomenele nu sunt liniare și statice, dar dinamice și ritmice. Sunt analizate probleme de logică și de metodologia științei, iar principiul antagonismului contradictoriu în cadrul logicii sale admite existența unei funcții dinamice, structurale și contradictorii. Diversitatea elaborărilor științifice în domeniu denotă existența unui pluralism ce poate fi interpretat diferit: fie ca impediment în calea înțelegerii proceselor și fenomenelor structural sistemice care se produc, fie ca un indicator al diferitor opțiuni care trebuie tratat ca ceva pozitiv. Ștefan Lupaşcu explică termenul etică specific episemologiei sale prin definirea în prefaţa operei „Omul şi cele trei etici ale sale”: „... prin termenul de etică înțeleg comportamentul, în acelaşi timp fizic, biologic şi psihic al omului, în contact cu fenomenele interne şi externe ale subiectului şi obiectului, ale inconștientului şi conștiinţei". Prin urmare reţinem comportamentul etic explicat prin dimensiunea fizică, biologică şi psihosocială.
\end{abstract}

Cuvinte cheie: etica, neoraționalismul dialectic, logica dinamică a contradictoriului, dimensiunea fizică, biologică şi psiho-socială, subiect, obiect
Citation: Inglis, I. (2021). De la tradiție la inovație în filosofia și metodologia științei contemporane: "Trietica contradictoriului" - Ștefan Lupașcu. Revista Etică și Deontologie, (1) 1, 95-103,

https://doi.org/10.52744/RED.2021.01.12

Publisher's Note: RED stays neutral with regard to jurisdictional claims in published maps and institutional affiliations.

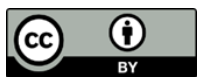

Copyright: (C) 2021 by the authors. Submitted for possible open access publication under the terms and conditions of the Creative Commons Attribution (CC BY) license (https://creativecommons.org/ licenses/by/4.0/).

\footnotetext{
${ }^{1}$ Articol prezentat în cadrul Conferinței Internaționale Valorile Etice în Societatea Actuală - VESA 2021 (3-5 iunie).
} 


\section{Introducere}

Știința contemporană este caracterizată prin: dezvoltarea accelerată, aspect interdisciplinar și multidisciplinar, aplicarea cunoștințelor științifice, tehnologii și metodologii care evoluează în continuu, integrarea activității de cercetare științifică cu activitățile de educație și instruire, mărirea efortului uman important pentru rezolvarea problemelor științifice și tehnologice la nivel național și internațional etc. Utilizarea tehnologiilor informaționale în activitatea științifică asigură o automatizare a proceselor de observare și prelucrarea rezultatelor experimentale obținute de către comunitatea științifică. De asemenea, se pune accentul pe formarea competențelor personale și profesionale a cadrelor științifice prin dezvoltarea instruirii continuă. Sintetizând problemele abordate din cadrul epistemologiilor contemporane, menționăm că se abordează ideile și metodele sinergeticii, dezvoltând paradigma integrității, aplicând principiul coevoluției, care determină importanța aspectului interdisciplinar și transdisciplinar în studierea obiectului de cercetare prin aplicarea metodelor filosofice.

0 abordare inovatoare în filosofia științei contemporane este prezentată de neoraționalismul dialectic la Ștefan Lupașcu prin formularea logicii dinamice a contradictoriului care se bazează pe cunoştințele ştiințifice din domeniile relevante ale științei de la jumătatea secolului al XX-lea, dorind concilierea ştiințelor şi filosofia. Ştefan Lupaşcu în volumul „Le Principe d'antagonisme et la logique de l'énergie”, expune principalele elemente ale logicii sale, urmărind evoluția cunoașterii ştiințifice în cele mai avansate domenii: microfizică, genetică, cibernetică, psihologie, lingvistică şi matematică, confruntând, verificând şi adaptându-şi ideile cu şi la cele mai recente descoperiri științifice (Ioan, 2000). El şi-a denumit logica dinamică a contradictoriului, determinînd eliminarea principiilor de identitate, pe cel al non-contradicției şi pe cel al terțului exclus, în beneficiul terțului inclus. Logica nominalizată este una a antagonismului contradictoriului, având caracter dialectic cu valori logice dinamicocontradictorii în fluxul neîntrerupt de actualizări şi potențializări. Logicii dinamică a contradictoriului se fundamenteză pe principiul antagonismului ca lege de bază, fiind considerată ca logică polivalentă, tripolară, transfinită care diferă esențial atât de logicile tradiționale, cât şi de cele dialectice sau logico-matematice: „Un fenomen, un element, un eveniment oarecare cu caracter logic este, prin constituția sa dualistă contradictorie, un dinamism implicând prin aceasta un dinamism contradictoriu, structural şi funcțional contradictoriu, încât orice actualizare dinamică implică o potențializare dinamică contradictorie şi orice non-actualizare sau non-potențializare, o non-actualizare sau non-potențializare contradictorie" (Lupasco, 1982).

\section{Contradicția la Ștefan Lupașcu}

Fundamentele științifice ale filosofiei „celui mai mare gânditor al secolului al XX-lea care lasă cu mult în urma lui pe de-alde Sartre, Husserl, Merleau-Ponty și alți 
succesori ai fenomenologiei, ori ai structuralismului" (Inglis, 2019, p. 218) sunt: principiul al doilea al termodinamicii, teoria relativității, teorema lui Zermelo, unele aspecte teoretice ale mecanicii cuantice: cuanta de energie a lui Max Planck, descoperirea naturii corpuscular-ondulatorii a luminii (Einstein), principiul incertiudinii (Werner Heisenberg), principiul complementarității (Niels Bohr), principiul de excluziune (Wolfgang Pauli), descoperirea spinului particulelor (J. Uhlenbeck și S. Goudsmidt), descoperirea pozitronului (Paul Dirac) ș.a. Descoperirile nominalizate sunt importante petru determinarea specificului dialecticii lupasciene, deoarece ele înfățișează multitudinea de forme prin care devine vizibil dualismul experienței microfizice, pe baza căruia se valorifică noua semnificație a conceptului de contradicție prezentat de filosoful român.

La Ștefan Lupașcu, sensul contradicţiei diferă de cel pe care i-l acordă logica formală. Pentru el contradicția nu are loc numai între propoziții, ci în cadrul întregului spectru al gândirii și al realității. Prin urmare, el nu înregistrează contradicția, ci observă specificul și modalitatea ei de funcționare. În spectrul noilor descoperiri științifice, procesul cunoașterii trebuie reevaluat din punct de vedere logic și epistemologic, deoarece pentru Ștefan Lupașcu epistemologia ne arată că spiritul uman se determină prin evitarea sau transcenderea continuă a unei dualități de realități sau de ordine antagonistă pe care le-am putea simboliza prin noțiunile de intensitate și extensitate: dualitate pur logică, acordându-i contradicției rolul de factor euristic cu mare putere predictivă în domeniul cunoașterii științifice, iar acest lucru nu îl putea realiza decât dacă își asuma riscul de-a pune sub semnul îndoielii aspectul absolut a logicii aristotelice. În acest sens, concepția lupasciană poate fi considerată ca un răspuns la următoarea întrebare: „Ce se va întâmpla dacă se neagă caracterul absolut al principiului non-contradicției, dacă se introduce contradicția, o contradicție ireductibilă în structura, funcțiile și operațiile înseși ale logicii?" (Lupașcu, 2000a, p. 5). În viziunea tradițională, contradicția se determină ca anomalie, ce trebuie să fie exclusă, însă Ștefan Lupașcu valorifică contradicția, din punct de vedere logic și epistemologic, ca pe un factor important în progresul cunoașterii. Prin urmare, logica propusă de Ștefan Lupașcu este definită ca „știința primă a dinamismelor contradictorii din orice experiență", ceea ce determină un aspect foarte important în problema cunoașterii (Colocviu international, 2010, p. 22).

Vom prezenta în continuare pe scurt momente din biografia marelui epistemolog român (Anale științifice, 2001): Ştefan Lupașcu (11.08.1900-07.11.1988) provine dintr-o familie de boieri moldoveni, tatăl său fiind politician şi avocat. În 1916 a migrat în Franța, unde a trăit toată viața. A studiat la Lycée Buffon, Paris unde a susținut bacalaureatul în 1920. Între anii 1924-1927, a studiat filosofia, biologia şi fizica la Sorbona, unde şi-a luat licența în 1928. În 1935 a publicat prima sa opera filosofică, teza de doctorat intitulată „Du devenir logique et de l'affectivité”, susținută la Sorbona, sub conducerea lui Abel Rey. Teza a fost publicată în două volume: „Le dualisme antagoniste et les exigences historiques de l'esprit" și "Essai d'une nouvelle théorie de la connaissance”. A publicat, în acelaşi an, o teză complementară - „La physique macroscopique et sa portée philosophique". În 1940 a publicat la Fundația Regală pentru Literatură şi Artă în România „Experienţa microfizică şi gândirea umană”. După război, în 1946, Ştefan 
Lupaşcu a fost numit cercetător la C.N.R.S. (Centre National de la Recherche Scientifique), la secțiunea epistemologie, iar în 1947 i-a aparut volumul „Logique et contradiction”. În 1951 a publicat „Le principe d'antagonisme et la logique de l'énergie Prolégomènes à une science de la contradiction”, în cadrul căreia a enunțat pentru prima dată principiul antagonismului, pe bazele căruia a fundamentat o logică non-aristotelică (a terțului inclus). În 1960 a aparut „Les trois matières”, apoi a urmat „L'énergie et la matière vivante” (1962), „Science et art abstrait” (1963), „La tragédie de l'énergie” (1970), „Qu'est-ce qu'une structure?” (1971), „Du rêve, de la mathématique et de la mort” (1971), „L'énergie et la matière psychique” (1974). A aparut „Psychisme et sociologie” (1978) şi „L'univers psychique” (1979), iar în 1984 a primit premiul Academiei Americane de Arte şi Ştiințe. În 1986 a publicat ultima sa carte, „L'homme et ses trois éthiques", în colaborare cu Solange de Mailly-Nesle şi Basarab Nicolescu şi în 1987 a devenit membru fondator al Centre International de Recherches et Études Transdisciplinaires (C.I.R.E.T.). Opera sa a fost apreciată de-a lungul timpului de către diferiți oameni de vază a culturii universale printre care se numără: Bernard d'Espagnat, Basarab Nicolescu, Edgar Morin, Gilbert Durand, Georges Mathieu, Salvador Dali, Michel Camus, Thierry Magnin, etc.

Ca un epistemolog inovator, Ștefan Lupașcu pledează pentru un dialog deschis cu noile descoperiri științifice. Se propune o teorie a cunoașterii bazată pe dualitate antagonistă în care fenomenele nu sunt liniare și statice, dar dinamice și ritmice. Cunoașterea este privită ca dualitate dintre actualizare și potențializare. Sunt analizate probleme de logică și de metodologia științei, iar principiul antagonismului contradictoriu în cadrul logicii sale admite existența unei funcții dinamice, structurale și contradictorii. Ștefan Lupașcu propune în acest sens o logică dinamică a contradictoriului, deoarece se vrea o dialectică a energiei și a contradictoriului, întrucât „postulează contradicția relativă ireductibilă ca fiind imanentă energiei și constituind liantul dintre dinamismele energetice antagoniste în sisteme" (Lupasco, 1982, p. 28).

Analizând diferite tipuri de materie: anorganică, cât şi organică, procesele din micro- şi macro-lume se formulează logica dinamică a contradictoriului. El studiază corelația dintre materie şi energie din teoria relativității lui A. Einstein, discută despre principiul antagonismului şi logica energiei, despre logica contradictoriului, despre cele trei materii, pornind de la materia din micro- şi macrolume şi materia vie, trecând în continuare la analiza materiei nevii, vii şi a materiei vii cu sistem nervos (materie psihică), analiza şi cele trei tipuri de materii - energii corespunzătoare (Lupasco, 1982, p. 29).

Teza conform căreia realitatea este structurată pe trei niveluri de materialitate a fost publicată în 1960 în eseul „Cele trei materii”, considerată ca „discursul asupra metodei din timpurile noastre” (Lupașcu, 1992, p. 32). Pentru a explica viziunea triontică asupra lumii, autorul pornește de la câteva premise fundamentale: materia este forma „unei sistematizări energetice dotată cu o anumită rezistență”, prin urmare, orice obiect al cunoașterii ni se prezintă ca un sistem sau ansamblu de evenimente energetice, orice sistem fiind rezultatul echilibrării variate dintre forțele antagoniste constituente. Legea sine qua non a oricărei sistematizări este aceea că 
aceasta nu poate fi posibilă fără luarea în calcul a conflictului său inerent, tocmai de aceea principiul esențial al logicii energiei se numește principiul antagonismului. Complexitatea acestor relații formatoare este direct proporțională cu complexitatea sistemelor de sisteme luate în calcul. Examinarea acestor sisteme complexe înfățișează „trei orientări privilegiate” ale sistematizării energetice care organizează materia în trei tipuri de structuri. Se presupune posibilitatea unui sistem de sisteme cu antagonism simetric, al stării T și alte două sisteme aflate în echilibru disimetric, inverse unul altuia, dominate de un anumit dinamism sau sistem în care relațiile de antagonism sunt mai slabe, ceea ce le conferă acestora un aspect mai pronunțat de materialitate. Cele trei sistematizări posedă logici sau orientări logice proprii cu legi specifice fiecăreia, cu tipuri de metode conceptuale și tehnice menite să ajute procesul cunoașterii lor. Cele trei materii sunt: materia-energie (macro) fizică, materia-energie biologică, materia-energie cuantică similară energiei psihice (Lupașcu, 2000b, p. 256). Se menționează că acestor trei tipuri de materii le corespund trei tipuri de cauzalitate, trei tipuri de spațio-temporalitate, trei tipuri de sisteme și sistemogeneze, trei tipuri de structuri și tot atâtea tipuri de dialectici (Colocviu international, 2010, p. 290).

Într-o lume, în care reprezentarea indeterministă este preferată celei deterministe, unde evoluția şi entropia devin compatibile, noile structuri superior organizate pot să apară în urma interferenței non-echilibrului, ireversibilității şi instabilității. Deci concluzia: la fel ca şi în cazul ființelor umane, punerea în lumină a complexităţii şi frumuseții naturii nu se poate înfăptui prin dominare şi control, ci prin cooperare şi dialog. Cele şapte concepte ale logicii lui Ștefan Lupaşcu - potențializare, actualizare, omogenizare, eterogentare, devenire, dezvoltare şi opusul acesteia, afectivitatea sunt explicate pornindu-se de la principiul energiei. Logica dinamică a contradictoriului se consideră multivalentă, având o arie mai largă de logicitate, o logicitate graduală care depăşeşte logicul şi ilogicul. Într-o așa logică, contradicția nu este între dinamic şi static, activ şi pasiv, ci între două sau mai multe dinamisme, între dinamismul dinamismului şi dinamismul staticului. Laturile contradicției dinamice tind spre antagonism prin actualizări şi potențializări succesive, specifice, în funcție de cele trei tipuri de existență a materiei: materia macrofizică, cea biologică şi cea neuro-psihică. Fiecărui nivel de organizare a materiei îi corespunde o anumită stare a energiei: energia omogenizantă ține de domeniul macrofizic, cea eterogenizantă corespunde nivelului biologic, iar energia antagonică (a stării T) susține structurile neuro-psihice.

Ştefan Lupaşcu pleacă de la contradicție şi ajunge la contradicție. Lumea anorganică este în stare de omogenitate crescândă, în timp ce eterogenitatea descrește, iar lumea organică se caracterizează printr-un raport invers între omogenitate şi eterogenitate; aceasta înseamnă că, în acest domeniu, atunci când omogenul se actualizează, eterogenul se potențializează, iar când eterogenul se actualizează, omogenul se potențializează. Potența este nimic şi, totuşi, este ceva fără de care actul nu poate fi act: secund din punct de vedere logic şi adevărat din punct de vedere ontic. Pentru acest filosof, nu există o limită de netrecut între materie şi spirit, astfel încât, la nivel cuantic, se poate vorbi despre existența unei speciale subiectivități dinamice, distincția materie-spirit acoperă parțial distincția 
potențializare - actualizare. În logica, sa, antagonismul este o formă de contradicție dinamică în schimbare, iar nu un raport static de opoziție contrară, astfel că această logică „este strîns legată de apariția epistemologiilor moderne, în care predomină principiile unei logici mai cuprinzătoare; logica clasică, formală [...] va fi considerată, față de aceasta, drept un caz polar, ideal" (Lupasco, 1982).

După Ştefan Lupaşcu, a cunoaşte înseamnă a exista şi a exista înseamnă a cunoaşte, cunoaşterea, ştiința şi existența fiind sediul contradicționalului, al cunoaşterii cunoaşterii, dar şi al fugii „de cunoaşterea cunoaşterii care nu mai este cunoaştere ci o întrebare pusă”. Logica dinamismului contradictoriu restrînge logica clasică, binară, admițând coexistența a trei termeni asociați de autorul ei, după cum s-a mai spus, la trei tipuri de „materii-energii”, trei feluri de finalități, de spațiu-timp, de comportamente, de ortodeducții etc. Din această perspectivă, Lupaşcu valorifică şi alte concepte precum cele de structură, sistem, atracție - repulsie, relație - ruptură, dar şi acele forțe antagonice, fie spre omogenizare fie spre eterogenizare.

Este interesant de urmărit, având în vedere presupozițiile logico-filosofice lupasciene, modul în care autorul „Logicii dinamice a contradictoriului” surprinde procesul cunoaşterii, prefigurând paradigma transdisciplinarității. Conform teoriei sale, dezvoltată în numeroase lucrări, subiectul şi obiectul cunoaşterii apar ca produse funcționale ale operației logice, alcătuind structura contradictorie a adevărului. Deosebit de semnificativ, relația dintre ele este, înainte de toate, proces, astfel încât se pot evita absolutizările, ințelegerile simpliste, unilaterale ale celor doi „poli” logici şi epistemsologici. La nivelul simțului comun, subiectul pare exclus din procesul cunoaşterii, fiindcă aceasta este îndreptată asupra a ceva ce e obiect. Sursele cunoaşterii psihologice individuale se consideră a fi, în principal, două: una internă (datele conştiinței), cealaltă externă (datele comportamentului observabil). Obiectivitatea acestei cunoaşteri se dobândește prin extensiunea adecvată a autoobservației, care nu e reductibilă la introspecție (,privirea interioară”, percepția internă) - care ar trebui să fie redenumită mai adecvat „extrospecție”, aşa cum susține Ştefan Lupaşcu - ci conține şi faptele conduitei, activitățile proprii.

Cum ajunge individul uman la autocunoaştere? El reuşeşte aceasta numai depăşind introspecția „pură” şi intrând în universul cunoaşterii obiective (ceea ce implică, din perspectiva filosofiei lupasciene, o suită indefinită de actualizări şi potențializări. Ştefan Lupaşcu consideră că realitățile „interioare” sau psihologice pot fi considerate adevărate în măsura în care sunt obiective (obiect al cunoaşterii) sau reale în măsura în care constituie un adevăr obiectiv, independent de subiect. Problemele metacognitive insolubile cu mijloacele clasice constituie rezultatul firesc al logicului care se ignoră pe sine (ceea ce este valabil şi pentru cazul cunoaşterii psihologice). Excluziunea reciprocă a subiectului şi obiectului în cunoaştere are urmarea ignorării procesului cunoaşterii, fie acesta exercitat de către omul „evoluat”, ,complex”, „cultivat” etc., fiindcă şi el se supune, la rândul său, caracterului invers și contradictoriu al elementelor demersului cognitiv. Cum spune Ştefan Lupaşcu, „nu este acelaşi lucru să cunoști şi să cunoşti ceea ce cunoşti". Psihologia cognitivă, arată că cercetarea componentelor comportamentului inteligent (de exemplu cele care intervin în rezolvarea de probleme) prezintă o deosebită importanță pentru învățare şi cunoaştere. 


\section{Etica la Ștefan Lupașcu}

Dar ce înseamnă pentru Ştefan Lupaşcu termenul „etică”? Ştefan Lupaşcu explică termenul etică specific episemologiei sale prin definirea în prefața operei „Omul şi cele trei etici ale sale”: ,.... prin termenul de etică înțeleg comportamentul, în acelaşi timp fizic, biologic şi psihic al omului, în contact cu fenomenele interne şi externe ale subiectului şi obiectului, ale inconștientului şi conștiinței" (Lupașcu, 1999). Se pune întrebarea de ce anume trei etici? Autorul răspunde: „pentru că nu există doar o morală, doar un singur tip de activitate normativă a binelui şi răului, a bunului şi dăunătorului, a normalului şi patogenului, ci exact trei, iar omul este lăcaşul acestor trei orientări etice care se luptă între ele”. Ele sunt identificabile, dacă se „trece în planul condițiilor practice ale rezolvării problemelor pe care le pune lumea ființei umane, prin mijlocirea acestor trei tipuri de etică" (Lupașcu, 1999).

Deci, se explică morala prin trei tipuri ale acesteia, sau treu tipuri de activități normate. Dimensionarea acestor tipuri trebuie să fie în acord cu prezentarea omului ca ființă bio-psiho-socială. Corespunzător, cele trei etici poartă denumiri specifice: etica macrofizică (energia omogenizată), etica biologică (energia eterogenizată) şi etica neuropsihică (energia antagonistă). Fiecare din ele implică o condiție epistemologică corespunzătoare nivelului său, energiei sale. Menționăm că acestor trei tipuri de materii le corespund trei tipuri de cauzalitate, trei tipuri de spațio-temporalitate, trei tipuri de sisteme şi sistemogeneze, trei tipuri de structuri şi tot atâtea tipuri de dialectici şi etici.

Noua etică este favorizată de eterogenitate şi este superioară celei care este determinată de omogenitate, adică cea care are suport în logica clasică (aristotelică). Pentru Ştefan Lupaşcu subiectul este sediul nu a două, ci a trei orientări, dimensiuni. Viața morală oscilează nu doar între pozitiv - negativ, bine-rău, normal-patogen, benefic-dăunător etc, ci este prezent și cel de-al treilea termen, mediu între aceste extreme, şi anume virtutea.

Virtutea presupune starea de trezire a „conştiinței conştiinței” şi „cunoaşterea cunoaşterii” - starea T - „o stare de echilibru şi de conflict contradictoriu dintre cele mai intense ca şi de cea mai densă energie”, „,centrul de control şi de necondiționalitate, de libertate”, stare „a semi-actualizării” şi „semi-actualizării” (Lupasco, 1982).

În cadrul a trei capitole (IV-VI), Ştefan Lupaşcu prezintă cele trei etici. Drumul urmat de autor se dovedește necesar pentru înțelegerea corectă a celei de-a treia etici. Precizează chiar el acest moment: „pentru a percepe această a treia etică umană, trebuie să acordăm importanța cuvenită parametrilor macrofizici şi biologici în sînul psihismului, să-i arătăm cerințele şi dereglările şi să căutăm mijloacele necesare pentru a-i remedia neajunsurile". Şi ca urmare subliniază autorul „cercetarea științifică nu mai poate ignora aceste trei tipuri de structuri ale materiei-energii, înverşunîndu-se a reduce întregul comportament etic al omului la legile fizice în care integrează biologicul şi psihismul, sau încercînd a reduce psihismul la biologic". Omul este, după Ştefan Lupaşcu „lăcaşul acestor trei orientări etice, care se luptă în el” (Lupașcu, 1999). Rolul educației şi al autoeducației este important în asigurarea echilibrului stării T, solicitând evidența enormă a „cunoaşterea cunoaşterii şi a 
necunoaşterii”, de asemenea „conştiința conştiinței şi a inconştiinței”. Activitatea şi creativitatea omului sunt semnificative pentru producerea varietății lumii exterioare, iar de aici decurge modul și rolul libertății, respectiv al responsabilității sale.

Conform epistemologiei lupasciene, cunoașterea este un proces complex care îl însoțește și-l angajează pe savant pe tot parcursul dezvoltării lui și nu este pur și simplu un act. A descrie și a explica cunoașterea înseamnă a descrie și a explica conținutul, originea și valoarea ideilor, locul și rolul lor în contextul raportului dintre lume și om (Lupașcu, 1992, p. 308). Sursele cunoașterii psihologice individuale se consideră a fi, în principal, două: una internă (datele conștiinței), cealaltă externă (datele comportamentului observabil). Obiectivitatea acestei cunoașteri se dobândește prin extensiunea adecvată a autoobservației, care nu e reductibilă la introspecție („privirea interioară”, percepția internă), ci ar trebui să fi e redenumită mai adecvat „extrospecție”, așa cum susține Ștefan Lupașcu - ce conține și faptele conduitei, și activitățile proprii. Așadar, introspecția trebuie controlată și suplimentată cu mijloace obiective (chestionare, teste), care demonstrează modul cum este ea influențată și ce anume o infl uențează. Mărturiile introspecției (spre exemplu, jurnale intime, opere literare ș.a.) nu sunt, propriu-zis, cunoaștere științifică; informațiile furnizate de ele sunt doar fapte care vor trebui interpretate în lumina unor teorii sau paradigme psihologice (Lovinescu, 1992, p. 184). Cum spune Ștefan Lupașcu, „nu este același lucru să cunoști și să cunoști ceea ce cunoști". Psihologia cognitivă, bunăoară, arată că cercetarea componentelor comportamentului inteligent (de exemplu, cele care intervin în rezolvarea de probleme) prezintă o deosebită importanță pentru învățare și cunoaștere.

Un rol foarte important pentru Ștefan Lupașcu îl joacă afectivitatea. Departe de a fi ceva pur subiectiv, afectivitatea apare ca „element” ontologic, fundamental și universal. Știința secolului XX, prin mecanica cuantică a demonstrat că subiectul observator infl uențează prin insuși actul observației desfășurarea fenomenelor cuantice. Ideile lui Ștefan Lupașcu, în primul rând principiul terțului inclus și principiul afectivității, prefigurările cunoașterii de dincolo de limitele disciplinare, împreună cu toate celelalte laturi ale onto-logicii sale trialectice a contradicției au fost întregite, sintetizate și explicitate de mulți savanți din diferite domenii ale științei contemporane. Iar logica lupasciană e o încercare de depășire a crizei științei din secolul al XX-lea (T,apoc, 2003, p. 27).

C. Noica a scris o prefață extraordinară, evidențiind esența originalității discursului filosofic lupascian: „În orizontul, conștient limitat, al dualismului antagonist încăpea de fapt foarte mult: întreaga lume de cunoscut, căreia i se propune o explicație unitară. Cel căruia o asemenea explicație i se pare mult prea cutezătoare, ca și cel care, sub o reținere sau alta, n-ar accepta-o ca atare, ar trebui totuși să recunoască filosofiei lui Lupașcu un merit cu adevărat remarcabil, acela de a fi repus în discuție trei distincții obsesive pentru istoria gândirii: deosebirea dintre materie și spirit, care se relativizează în concepția lui, deosebirea subiect-obiect, care iese din îngustimea ei, subiectivitatea revenind nu doar „conștiinței”, ci oricărui dinamism activ, deosebirea dintre formal și material, care își schimbă fundamental înțelesul. Nu știm care filosofie occidentală din veacul al XX-lea și-a propus atât de mult..." (Lupasco, 1982, p. 14). 


\section{Concluzii}

Ștefan Lupașcu a creat o concepție logico-filosofică anticipatoare pentru paradigma epistemologiei contemporane. Reconsiderarea personalității umane (în special al savantului) din această perspectivă ar avea pe termen lung consecințe de o valoare enormă, dat fiind că științele umaniste au avut și încă mai au tendința de a supralicita exclusive dimensiunea afectivității, intelectual-analitică și rațional-operațională a ființei umane.

Astfel, meritul istoric al lui Ștefan Lupașcu este acela de a fi recunoscut faptul că infinita multiplicitate a realului poate fi restructurată şi derivată plecând de la numai 3 termeni (triadă) - idee pe care a urmărit-o şi dezvoltat-o cu o rară consecvență în întreaga sa operă filosofică. Deci aceste trei sistematizări energetice sau materii posedă logicile proprii cu legile lor specifice şi necesitățile deductive, ca şi metodologiile conceptuale şi tehnice, tipurile de metode ce ne permite să le cunoaştem, să acționăm asupra lor şi chiar să le producem.

\section{Referințe}

Anale științifice, (2001). Lupaşcu, Ştefan: un gânditor pentru mileniul trei. Vol I-II din Analele ştiințifice ale Institutului de Studii Europene "Ştefan Lupaşcu": Institutul de Studii Europene Ştefan Lupaşcu, Iaşi. 2001.

Colocviu international, (2010), La confluenţa a două culturi: Lupasco astăzi/edditor Basarab Nicolescu, Lucrările Colocviului Internațional UNESCO. Lucrare apărută în cadrul programului „Ştiință şi Ortodoxie - Cercetare şi Educație”. Paris, 24 martie. Bucureşti, Editura Curtea Veche, 2010.

Inglis, I., (2019), Unitatea dintre dialectică, logică şi epistemologie din perspectiva neoraţionalismului dialectic al lui Ștefan Lupașcu, https://ibn.idsi.md/sites/default/ files/imag_file/217-227_1.pdf

Ioan, P., (2000). Ştefan Lupaşcu şi cele trei logici ale sale, Iaşi, Editura „Ştefan Lupaşcu”, 2000.

Lovinescu, M., (1992), Întrevederi cu Mircea Eliade, Eugen Ionescu, Ştefan Lupaşcu şi Grigore Cugler. București, Editura Cartea Românească, 1992.

Lupasco, S., (1982). Logica dinamică a contradictoriului, Editura Politică, București.

Lupașcu, Șt., (1992), Experiența microfizică şi gândirea umană. București, Editura Ştiințifică, 1992.

Lupaşcu, Şt., (1999), Omul şi cele trei etici ale sale, Iaşi, Editura „Ştefan Lupaşcu”, 1999.

Lupașcu, Şt., (2000a), Principiul antagonismului și logica energiei, Iași, Editura "Ş̦tefan Lupașcu”, 2000.

Lupaşcu, Ş., (2000b), Universul psihic: sfârşitul psihanalizei. Iaşi, 2000.

Țapoc V., (2003), Ştefan Lupascu la Chişinău, în „Şttiințe socio-umanistice şi progresul tehnicoștiințific", UTM, Chişinău, 2003. 